\title{
抗痙攣剤服用児にみられた骨病変の検討
}

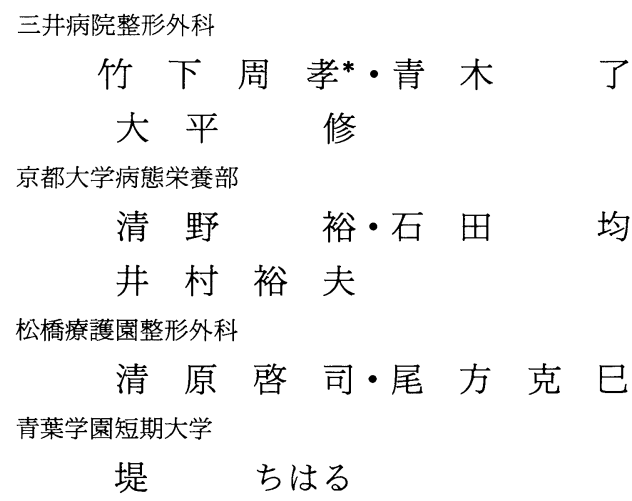

\section{A Study of Osteopenia in Children on Anticonvulsant Therapy}

by

\author{
Noritaka Takeshita*, Satoru Aoki and Osamu Oohira \\ Department of Orthopaedic Surgery, Mitsui Hospital \\ Yutaka Seino, Hitoshi Ishida and Hiroo Imura \\ Department of Metabolism and Clinical Nutrition, \\ Kyoto University School of Medicine ; \\ Keiji Kiyohara and Katsumi Ogata \\ Department of Orthopaedic Surgery, Matsubase Ryogoen

\section{Chiharu Tsutsumi} \\ College of Aoba
}

In order to investigate the pathophysiology of anticonvulsant induced osteopenia, circulating levels of bone $\gamma$-carboxyglutamic acid containing protein (BGP) and urinary excretion of BGP were measured in sixteen childlen on chronic anticonvulsant therapy and twelve control children. Using microdensitometry analysis, osteopenia was found in $25 \%$ of the anticonvulsant therapy group, but was not observed in the control group. Serum levels of BGP and A1-P were significantly increased in the anticonvulsant group compared to those in control group $(\mathrm{P}<0.05, \mathrm{P}<0.01)$, respectively.

Urinary excretion of BGP and Hydroxyproline showed a increasing tendency in the anticonvulsant group, but it was not statistically significant. There was no significant difference in serum levels of Vit D metabolites, PTH, calcitonin, Ca, P or urinary excretion of $\mathrm{Ca}, \mathrm{P}$ between the two groups. It is suggested, therefore, that increasing BGP levels in children receiving anticonvulsant therapy is responsible in part for the occurrence of anticonvulsant induced osteopenia.

目的

抗痙攣剂長期服用中に骨軟化症などの骨病変の生じ

*京都大学病態栄養部
ることが知られているが，その成因や病態については なお明らかでない。一方，近年カルシウム結合蛋白で ある $\gamma$-carboxy glutamic acid-containing protein (BGP) が骨皮質や血清中に存在することが明らかにさ 
れ,血清 BGP が種々の代謝性疾患の場合に変動するこ とが報告されている ${ }^{5)}$.そこで今回は抗痙攣剤服用児の 血清中の BGP を中心に検討を加えた。

\section{対象と方 法}

1. 対象：抗痙攣剂を 1 年以上服用中のてんかん児 16 名 (服用群：年令 $5.2 \sim 16.1$ 才, 性別 男 12 女 4 , 活動性独歩 8 車椅子 8 ） および非服用児 12 名（対照 群：年令 $4.3 \sim 15.2$ 才，性別 男 9 女 3 , 活動性 独 歩 5 車椅子 7 ) である.

2. 方法：Microdensitometry (MD) 法による骨病 変の解析および血中 BGP, Vit D メタボライト, PTH, カルシトニン, Al-P, Ca, P と尿中 BGP, Hypro, $\mathrm{Ca}$, $\mathrm{P}$ 排泄量を測定し, 両群で比較した。 $\mathrm{MD}$ 法による骨病 変の解析は黒瀬ら ${ }^{2)}$ の標準回帰式をもとに骨減少の有無 を判定した，BGPはPrice ら ${ }^{5)}$ の方法にしたがって anti-calf BGP rabbit serumを用いる Radioimmunoassay (RIA)により測定した (図 1)。25(OH)D, $1.25(\mathrm{OH})_{2} \mathrm{D}$ は competitive protain binding assay (CPBA) で, PTH, カルシトニンは RIA で各々測定し, 統計学的処理には Student's $t$ test を用いた。

結果

1. MD 法による解析：対照群では $100 \%$ が正常で あったが, 服用群では骨減少が $25 \%$ に認められ正常例 は 44 \%にすぎなかった（図 2)。さらに MD 法の名パ ラメーター別に比較すると，骨幅（D）は両群間で有 意差は認められなかったのに対し，皮質部骨密度 (GSmax)，髄質部骨密度（GSmin），平均骨密度

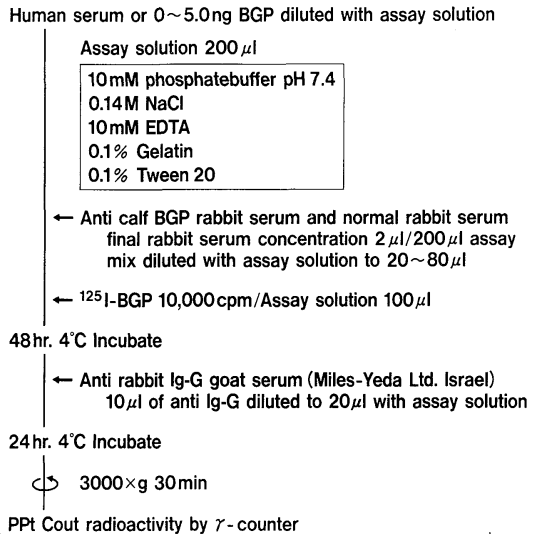

図 1 Radioimmunoassay for BGP
( $\Sigma \mathrm{GS} / \mathrm{D})$, 骨パターンは対照群を $100 \%$ とした場合， 服用群では各々 $83.9 \% ， 80.5 \% ， 84.3 \% ， 68.8 \%$ と
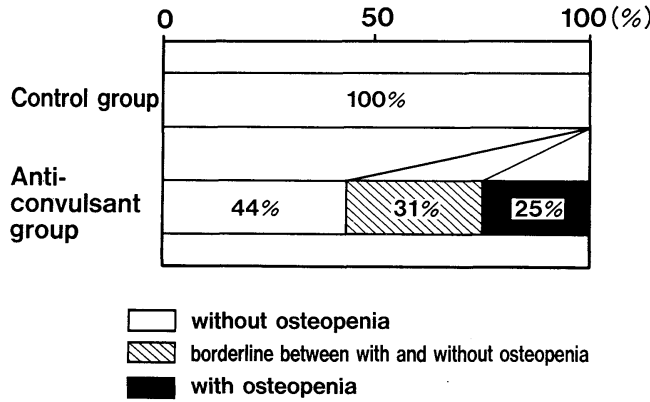

図 2 Frequency of osteopenia in Control group and Anticonvulsant group.

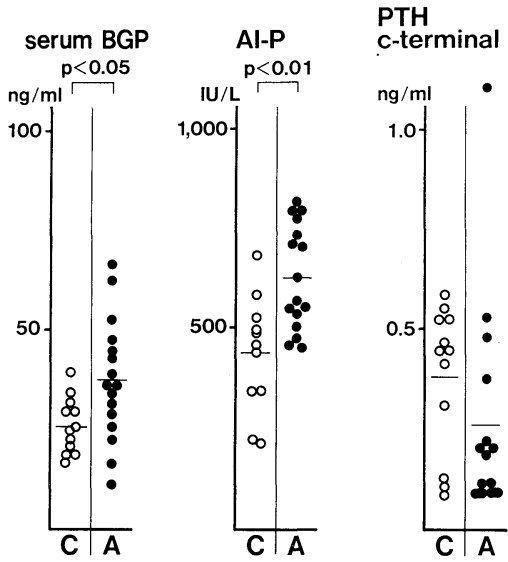

図 3 serum BGP, Al-P, PTH in Control (C) and Anticonvulsant therapy (A)

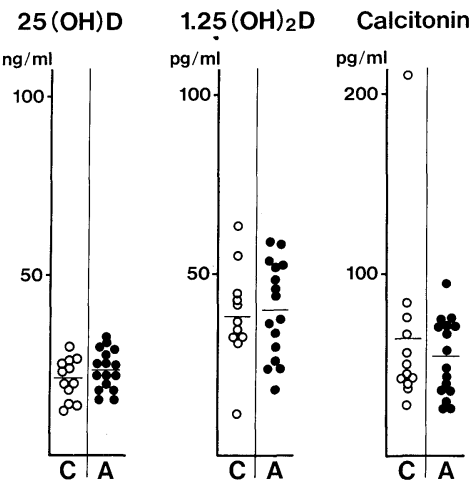

园 4 serum $25(\mathrm{OH}) \mathrm{D}, 1.25(\mathrm{OH})_{2} \mathrm{D}$, Calcitonin in Control (C) and Anticonvulsant therapy (A) 


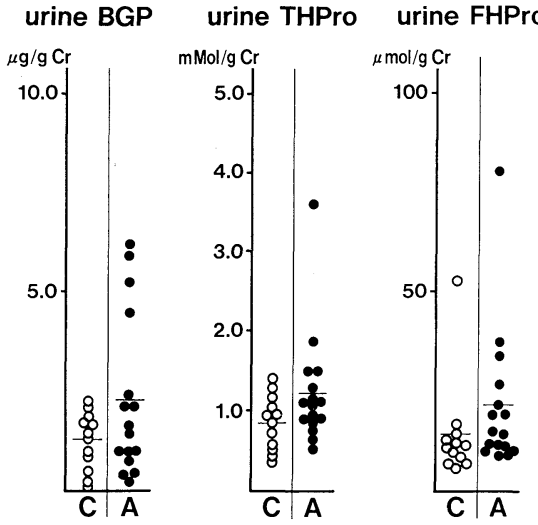

図 5 urinary excretion of BGP, THPro, FHPro in Control (C) and Anticonvulsant therapy (A)

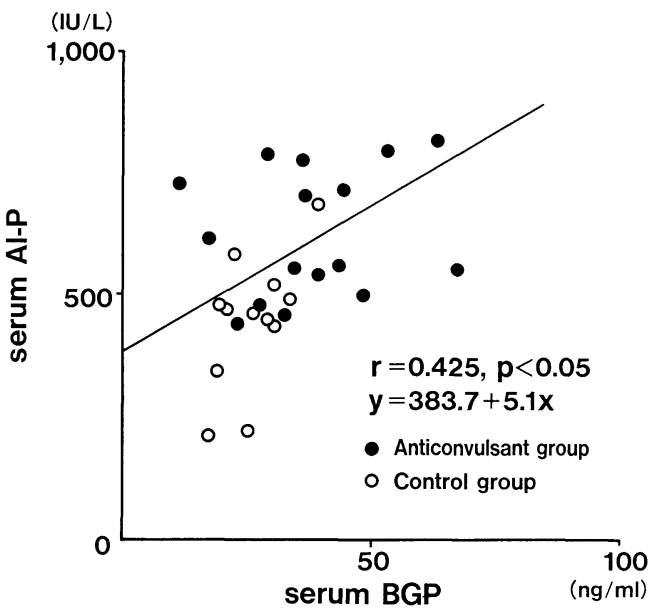

図 6 Correlation between serum levels of BGP and $\mathrm{Al}-\mathrm{P}$.

有意の低下を示した $(\mathrm{p}<0.01, \mathrm{p}<0.01, \mathrm{p}<0.01$ ， $\mathrm{p}<0.02)$.

2. 血液尿検查：血中 BGP は服用群で $37.4 \pm 3.8$ $\mathrm{ng} / \mathrm{ml}$ (Mean $\pm \mathrm{S}$. E.) と対照群の $25.9 \pm 2.0 \mathrm{ng} / \mathrm{ml}$ に 比し有意の上昇を示した $(\mathrm{p}<0.05$, 図 3$)$. 血中 $\mathrm{Al}-$ $\mathrm{P}$ も服用群で $629 \pm 33 \mathrm{IU} / \mathrm{L}$ と対照群の $442 \pm 40 \mathrm{IU} / \mathrm{L}$ に比し有意の上昇を示し $(\mathrm{p}<0.01$, 図 3$)$, かつ BGP と $\mathrm{Al}-\mathrm{P}$ 間に有意の正の相関が認められた $(\mathrm{p}<0.05$, 図 6 ). 血中 PTH は対照群に比し服用群で低下の傾向 にあったが有意ではなかった（図 3 )。25(OH)D, 1 . $25(\mathrm{OH})_{2} \mathrm{D}$, カルシトニン, $\mathrm{Ca}, \mathrm{P}$ は両群間で有意差は 認められなかった（図 4 )。一方, 尿中 BGP, totalHypro, free-Hypro 排泄量は対照群に比し服用群で増
加の傾向にあったが有意ではなかった(図 5 ). 尿中 Ca， $\mathrm{P}$ 排泄量は両群間で有意差は認められなかった。

$$
\text { 考察 }
$$

Schmid $ら^{6)}$ が抗痙攣剂長期服用時のクル病の発症を 報告して以来，骨病変は抗㾏攣剤の慢性副作用の 1 つ として注目されている.さらに Hahn ら ${ }^{1)}$ が抗痙攣剤服 用患者に $25(\mathrm{OH}) \mathrm{D}$ の低下を報告し, 本疾患と Vit D 代 謝異常との関連が注目されている.一方, Weinstein ら は抗痤攣剤服用患者に Vit D の異常を認めず, 組織学 的に骨の turn over の異常の存在を明らかにし，中村 $ら^{3)}$ も本疾患における抗痙攣剤の骨への直接的作用の関 与を示唆している. 近年 BGP は骨形成に関与しており, 血中 BGP 值が Al-P と同様に骨芽細胞の活動性を反 映し4)，しかもその合成は $1.25(\mathrm{OH})_{2} \mathrm{D}$ により調節され ることが明らかにされている。

今回の成績では Vit D メタボライトに差はみられず, 服用群で BGP，Al-P 上上昇が認められた。したがつ て薬剤の骨への直接的関与の可能性が推測された。

結 論

抗痙攣剂服用児では約 $25 \%$ に骨減少が認められ，同 時に血中 BGP の上昇, 尿中 BGP 排泄量の増加傾向も 認められた.したがってこの BGP の上昇が抗痙攣剤 服用児に生じる骨病変の成因や病態と密接に関係して いる可能性が示唆された。

\section{参 考 文 献}

1) Hahn. T. J. et al. : Effect of chronic anticonvulsant therapy on serum $25(\mathrm{OH}) \mathrm{D}$ levels in adults. New. Eng. J. Med. 287 : 900-904, 1972.

2）黒瀬裕史：X線像による小児の骨成長の判定. 骨代 謝, $14: 319-325,1981$.

3）中村利孝：抗痤攣剤による骨軟化症について.骨代謝, $12: 228-237,1979$.

4) Otawara Y. et al. : Effect of aging and castration on the changes in the levels of Bone $\gamma$-carboxy glutamic acid-containing protain in bone and serum of female rats. J. Nutr. Sci. Vitaminol. 29 : 249-260, 1983.

5) Price P.A. et al.: New biochemical marker for bone metabolism. J. Clin. Invest. 66: 878-883, 1980.

6) Schmit F.: Osteopathien bei antiepileptischer Dauerbehandlung Fortser. Med. 85 : 381-382, 1967.

7) Weinstein R. et al. : Decreased serum ionized calcium and normal vitamin D metabolite levels 
with anticonvulsant drug treatment. J. Clin. Endocrinol. Metab. 58 : 1003-1009, 1984.

\section{質 問琉球大学 乗松 尋道}

対象患者が障害児ですので運動能力, 食事摄取能力 が骨変化を左右する因子となりますか. その点は検討 されましたでしょうか.
解 答
三井病院 竹下 周孝
(1) 運動能力については,

独歩可能群と独歩不能（車椅子移動）群とで比較し てみますと, やはり独歩不能群に骨減少を有する症例 が多いので, 運動能力は骨変化を左右する一つの因子 として考えられると思います。

(2) 食事摂取能力については, 全例が自力で摂取可能でしたので，比較検討してお りません。 